3. Кримінальний кодекс Республіки Молдова. URL: http://continent-online.com/Document/?doc_id=30394923\#pos=2637;38 (дата звернення: 18.04.2021).

4. Закон про кримінальне право Ізраїлю. URL: http://library.khpg.org/ files/docs/1375279180.pdf (дата звернення: 18.04.2021).

5. Федеральний «Закон про захист від інфекцій» (Infektionsschutzgesetz, IfSG). URL: https://www.gesetze-im-internet.de/ifsg/ (дата звернення: 18.04.2021).

DOI https://doi.org/10.30525/978-9934-26-074-2-49

\title{
БЕЗПРЕДИКАТНЕ РОЗСЛІДУВАННЯ ЛЕГАЛІЗАЦІЇ: МІФ ЧИ РЕАЛЬНІСТЬ ДЛЯ УКРАЇНИ
}

\author{
Красноборов О. В. \\ кандидат юридичних наук, \\ доцент кафедри кримінального та адміністративного права \\ Академії адвокатури України, \\ адвокат \\ м. Київ, Украӥна
}

Імплементація в національне кримінальне законодавство норм конвенцій Ради Свропи про відмивання, пошук, арешт та конфіскацію доходів, одержаних злочинним шляхом, повинна мати неабияке превентивне значення у боротьбі не тільки з легалізацією (відмиванням) майна, а й з іншими тяжкими злочинами, кінцевою метою яких є можливість інвестування здобутих злочинним шляхом доходів у реальний сектор економіки та подальше безперешкодне володіння і розпорядження набутими таким чином активами.

Утім, каменем спотикання на шляху до приведення нормативноправової бази України до європейських стандартів досі залишається питання запровадження механізму так званого безпредикатного розслідування легалізації (відмивання) майна, одержаного злочинним шляхом, що безумовно значно спрощує процес доведення вини особи у вчиненні цього злочину.

Водночас, щоб зрозуміти готовність нашої держави до практичної реалізації вказаного механізму, необхідно визначитися зі змістовним наповненням самого поняття «безпредикатність», що дедалі частіше вживається при розслідуванні злочинів указаної категорії. Чи це повне звільнення сторони обвинувачення від необхідності доведення 
злочинності походження доходів, що легалізуються (відмиваються), до прикладу, коли підозрювана особа банально не може надати жодних доказів законності набуття майна, яким вона фактично володіє; чи це тільки загальне обгрунтування кримінально протиправного (злочинного) шляху одержання майна, яке у подальшому легалізувалось (відмивалось), без необхідності точного встановлення конкретного злочину, внаслідок якого це майно було набуто?

Зазначене питання має сьогодні надважливе теоретичне та практичне значення, оскільки багато юристів, чуючи про безпредикатне розслідування легалізації, пов'язують його саме з першим випадком, коли нібито взагалі не потрібно доводити жодного предикатного злочину, а достатньо лише відсутності підтвердження законності одержання відповідних доходів (майна).

Усі вони до певної міри мають рацію, оскільки ратифіковані Україною і Конвенція Ради Свропи про відмивання, пошук, арешт та конфіскацію доходів, одержаних злочинним шляхом, від 8 листопада 1990 року [1], і Конвенція Ради Свропи про відмивання, пошук, арешт та конфіскацію доходів, одержаних злочинним шляхом, та про фінансування тероризму від 16 травня 2005 року [2] (далі - Варшавська конвенція) визначають «предикатний злочин» фактично як один зі складових елементів відмивання доходів, без якого легалізація взагалі неможлива.

3 огляду на це, саме вживання терміну «безпредикатність» при розслідуванні легалізації (відмивання) доходів $\epsilon$ не зовсім коректним, оскільки навіть в розумінні статті 209 Кримінального кодексу України [3] (далі - КК України) легалізованим (відмитим) може бути лише майно, одержане злочинним шляхом, тобто внаслідок вчинення якоїсь конкретної злочинної діяльності, в результаті якої й виникли доходи, що стали предметом подальшої легалізації.

Тож, оскільки суть відмивання доходів полягає у наданні набутому саме злочинним шляхом майну певного легального (законного) статусу, правильнішим, напевно, є розуміння безпредикатності саме в світлі встановлення певної кримінальної протиправності (злочинності) природи набуття відповідного майна, без необхідності точного встановлення конкретного злочину, в результаті якого це майно було одержано.

Не менш важливо зазначити й про інші аспекти, які й досі не дають можливості на практиці відмовитись від встановлення конкретного злочину чи злочинів, які передували легалізації, ставлячи під сумнів ефективне запровадження так званого безпредикатного розслідування легалізації в Україні. 
Так, незважаючи на те, що остання редакція статті 209 КК України, яка набрала чинності 28 квітня 2020 року, нібито й позбулась одного 3 пунктів примітки, який зобов'язував сторону обвинувачення чітко доводити конкретний предикатний злочин, вказане положення фактично нікуди не зникло, а, дещо трансформувавшись, перемістилося у Закон України «Про запобігання та протидію легалізації (відмиванню) доходів, одержаних злочинним шляхом, фінансуванню тероризму та фінансуванню розповсюдження зброї масового знищення» [4] (далі Закон), яким й були внесені відповідні зміни.

Так, пункт 23 частини 1 статті 1 вказаного Закону чітко встановлює, що «доходи, одержані злочинним шляхом, - будь-які активи, одержані прямо чи опосередковано внаслідок вчинення злочину» [4].

I хоча частина 5 статті 9 Варшавської конвенції «забезпечує відсутність визнання попереднього або одночасного засудження за предикатний злочин як передумови для засудження за відмивання грошей» [2], вона жодним чином не звільняє сторону обвинувачення від необхідності обгрунтування кримінальної протиправності (злочинності) шляху одержання цих грошей.

Також не потрібно ігнорувати й Закон України «Про ратифікацію Конвенції Ради Свропи про відмивання, пошук, арешт та конфіскацію доходів, одержаних злочинним шляхом, та про фінансування тероризму» [5], про який часто замовчують, оскільки Варшавську конвенцію було ратифіковано з певними заявами і застереженнями, в яких до статті 9 (Злочини з відмивання грошей) Україна заявила про те, що:

- «буде застосовувати пункт 1 статті 9 Конвенції тільки у випадках, коли за предикатний злочин передбачено покарання у вигляді позбавлення волі»;

- «не буде застосовувати пункт 6 статті 9 Конвенції» [5], в якому зокрема йдеться мова про так зване безпредикатне розслідування легалізації, тобто коли «кожна Сторона забезпечує можливість засудження за відмивання грошей відповідно до цієї статті, коли доведено, що майно, про яке йдеться в підпунктах «а» чи «b» пункту 1 цієї статті, походило з предикатного злочину, без необхідності точного встановлення якого саме» [2].

Крім вищезазначених законів частина 9 статті 216 Кримінального процесуального кодексу України [6] також фактично натякає на необхідність одночасного розслідування і легалізації (відмиванню) майна, i предикатного злочину, встановлюючи, що «у кримінальних провадженнях щодо кримінальних правопорушень, передбачених статтями 209 і 209-1 Кримінального кодексу України, досудове розслідування здійснюється слідчим того органу, який розпочав досудове 
розслідування або до підслідності якого відноситься кримінальне правопорушення, що передував легалізації (відмиванню) майна, одержаного злочинним шляхом» [6].

Отже, аналіз чинного національного законодавства в сфері легалізації (відмивання) майна, одержаного злочинним шляхом, дає підстави стверджувати, що притягнення будь-якої особи до кримінальної відповідальності за статтею 209 КК України наразі неможливе без встановлення хоча б якогось предикатного злочину. Звісно ж, якщо мова йде про повноцінний змагальний процес за активної участі в ньому сторони захисту.

Тож чи не єдиним практичним механізмом апробації безпредикатного розслідування легалізації в реальних умовах наразі може слугувати лише використання інституту угод у кримінальному провадженні, який передбачає випадки повного визнання винуватості підозрюваною особою, що теоретично дозволяє стороні обвинувачення обмежуватися незначним обгрунтуванням кримінальної протиправності (злочинності) природи походження майна та уникати чіткого встановлення конкретного предикатного злочину.

Утім, останні зміни в національному законодавстві про запобігання та протидію легалізації (відмиванню) доходів, одержаних злочинним шляхом, безумовно свідчать «про сталий курс до остаточної відмови вже у найближчому майбутньому від точного встановлення конкретного предикатного злочину, який передував легалізації, що корелюється із прогресивними світовими тенденціями в сфері боротьби з легалізацією (відмиванням) коштів та фінансуванням тероризму» [7, с. 205].

\section{Література:}

1. Конвенція Ради Європи про відмивання, пошук, арешт та конфіскацію доходів, одержаних злочинним шляхом: Конвенція Ради Європи від 08.11.1990. URL: https://zakon.rada.gov.ua/laws/show/995_029 (дата звернення: 05.04.2021).

2. Конвенція Ради Європи про відмивання, пошук, арешт та конфіскацію доходів, одержаних злочинним шляхом, та про фінансування тероризму: Конвенція Ради Європи від 16.05.2005. URL: https://zakon.rada.gov.ua/laws/show/994_948 (дата звернення: 05.04.2021).

3. Кримінальний кодекс України: Закон України від 05.04.2001 № 2341-III. URL: https://zakon.rada.gov.ua/laws/show/2341-14 (дата звернення: 05.04.2021).

4. Про запобігання та протидію легалізації (відмиванню) доходів, одержаних злочинним шляхом, фінансуванню тероризму та фінансуванню розповсюдження зброї масового знищення: Закон України від 
06.12.2019 № 361-IX. URL: https://zakon.rada.gov.ua/laws/show/361-20 (дата звернення: 05.04.2021).

5. Про ратифікацію Конвенції Ради Європи про відмивання, пошук, арешт та конфіскацію доходів, одержаних злочинним шляхом, та про фінансування тероризму: Закон України від 17.11.2010 № 2698-VI. URL: https://zakon.rada.gov.ua/laws/show/2698-17 (дата звернення: 05.04.2021).

6. Кримінальний процесуальний кодекс України: Закон України від 13.04.2012 № 4651-VI. URL: https://zakon.rada.gov.ua/laws/show/4651-17 (дата звернення: 05.04.2021).

7. Красноборов О. Ретроспектива законодавчого регулювання кримінальної відповідальності за легалізацію (відмивання) майна, одержаного злочинним шляхом. Підприємництво, господарство i право. 2020. № 12. C. 202-206. URL: http://pgp-journal.kiev.ua/archive/ 2020/12/36.pdf (дата звернення: 05.04.2021).

DOI https://doi.org/10.30525/978-9934-26-074-2-50

\title{
КРИМІНАЛЬНА ВІДПОВІДАЛЬНІСТЬ ЗА ВЧИНЕННЯ АКТІВ НЕЗАКОННОГО ВТРУЧАННЯ В ДІЯЛЬНІСТЬ ЦИВІЛЬНОЇ АВІАЦІЇ
}

\author{
Кундеус В. Г. \\ кандидат юридичних наук, доцент, \\ доцент кафедри кримінального права та кримінології \\ факультету № 6 \\ Харківського національного університету внутрішніх справ \\ м. Харків, Україна
}

В сучасному стані розвитку авіаційного транспорту акти незаконного втручання в діяльність цивільної авіації (далі - акти незаконного втручання) $є$ найбільш небезпечними посяганнями на безпеку авіаційного транспорту. Визначення кола актів незаконного втручання регламентуються міжнародними конвенціями, учасником яких є Україна: Конвенція про злочини та деякі інші акти, що вчинюються на борту повітряних суден від 14.09.1963 року, Конвенція про боротьбу з незаконним захопленням повітряних суден від 16.12.1970 року, Конвенція про боротьбу з незаконними актами, спрямованими проти безпеки цивільної авіації від 23.09.1971 року, Додаток 17 до Конвенції про 